\title{
Education by Correspondence in Russia: from Roots to the Present
}

\author{
Michael Dmitriev, Galina Zhukova, Tatiana Burukhina, Valery Sokolov \\ Moscow State Social University, Russia/ \\ Moscow State Social University, Russia/ \\ Moscow State Social University, Russia/ \\ Yaroslavl State University, Russia
}

Education is a powerful factor not only of the intellectual, spiritual, but also social and economic development of a society. Education today is an effective way of maintenance of survival, safety and transition to a steady development, since only an active role of the person, his culture, ideals and interests in a combination with the achievements of science and technology, appropriate forms of managing are a base of the steady development of the society. The dependence of goods production results of an erudition level of workers has made education all over the world the second-largest, after a military-industrial complex, industry of the XX century, has transformed it into one of significant global factors of the present.

The Russian society, when studying ways out of the crisis situation in which it appeared at the end of the XX century, considers the educational sphere as the most effective investment resource - the human potential is created here. In his speech at the session of the State Council, August, 29, 2001, Vladimir V. Putin noted that the development of education is put forward in a number of priority directions of the Russian state policy. The President of Russia emphasized that the state should restore its responsibility and its active role in the sphere of education, being guided by increasing availability, quality and efficiency of the domestic educational system, its conformity to vital needs of the country. Decisions of the State Council have laid a basis of the Concept of the Russian education modernization approved at the session of the Russian government in October, 21, 2001. According to this document, it is necessary to create a mechanism of a steady development of the educational system, which would correspond to requirements of the XXI century, to social and economic needs of the developing country, to inquiries of the person, the society and the state ${ }^{1}$.

Now the higher school of Russia experiences a very difficult period of its existence. On the one hand, needs in the higher education in the country continue to remain high. It is due to the fact that under conditions of market economy the presence of higher education increases competitiveness of the person on labour market, forms a basis of social growth and promotion, helps to be guided by and better adapted to varying social and economic conditions. The changes happened in our country in last decade resulted in the situation when many people had to change the character of their labour activity; in this connection, the necessity for additional or second education appeared.

On the other hand, already for more than ten years the deterioration of personnel

"Proceedings of the 2003 American Society for Engineering Education Annual Conference \& Exposition Copyright (C) 2003, American Society for Engineering Education" 
structure of educational establishments has been observed. There is a direct evidence of crisis tendencies: the fall in public prestige of the profession " Teacher of higher school", the physical ageing of higher school professors, the outflow of perspective young specialists to commercial structures and abroad. And though there is a tendency of increasing the number of the basic personnel of higher schools and the number of the teachers having a scientific degree of the doctor of sciences (from 6,1\% in 1991 up to $9,5 \%$ in 1997) ${ }^{2}$, it is connected with the aspiration of higher schools to keep highly skilled specialists who, having come from the academic and scientific institutes, have no due experience in pedagogical work. For the researchers who know the history of the Russian and Soviet higher school, it is not a secret that theoretical contents of education concepts and practical work of a teacher with students at the end of XIX - the beginning of XX century were considerably richer and more interesting than in the following decades. That is why it is necessary to analyse once again the work of the Russian and Soviet higher school in order to apply it to the modern practice.

The purpose of this work is to review the stages of formation of the education by correspondence in Russia, which was basically engineering in the Soviet period of the Russian history and remains to a great extent the same up to now.

The higher school history began in the XII century and up to the XVIII century it was represented, mainly, by universities. The rapid growth of material and industrial production, achievements in engineering and technologies, the growing value of science in the XIX century have resulted in turning education to an independent branch of culture. In 60-70 years of the XIX century universities experienced a rapid growth in all areas of their activity, the number of technical educational institutions increased, the pedagogics of the higher school arose.

The appreciable contribution to formation of an advanced pedagogical idea of that time was made by the oustanding scientists: N.I.Pirogov, V.V.Markovnikov, A.G.Stoletov, I.I.Mechnikov, D.K.Chernov, N.A.Umov, P.N.Lebedev, K.A.Timirjazev, D.I.Mendeleev, A.S.Popov, N.E.Zhukovsky, I.P.Pavlov. They created their scientific and pedagogical schools. Scientists of Moscow Higher Technical School A.V.Letnikov, N.A.Shaposhnikov, P.K.Hudjakov, A.P.Sidorov, A.P.Gavrilenko, V.I.Grinevetsky and some others created the Russian system of higher technical education based on the close connection of theoretical courses with practical training in industrial workshops and laboratories. The system received a wide recognition abroad as " Russian methods of training", and it was marked by the highest premiums and awards at the international exhibitions (in Philadelphia 1876, Paris 1900) ${ }^{3}$. At the same time there was no uniform government policy in the field of higher education. It was different at Alexander II, Alexander III and Nikolay II. It is possible to say that it was the policy of fluctuations between two approaches - conservative and democratic, as it was developed and carried out by various people and ministries and in many respects it depended on a political situation in the country.

One of the means of overcoming monopoly of the state in the sphere of higher education was occurrence of nongovernmental "free" higher school in the form of public universities. At the end of the XIX century Russia was one of the most backward European countries as far as the level of national education is concerned. According to the first general census of the population (1897) out of 125640 thousand inhabitants of Russia covered by the census, only $21,1 \%$ of habitants were literate (men $-29,3 \%$, women $-13,1 \%)^{4}$. However, the aspiration to

"Proceedings of the 2003 American Society for Engineering Education Annual Conference \& Exposition Copyright (C) 2003, American Society for Engineering Education" 
education, in particular, among workers of the large industrial enterprises, was high. "Educational needs of workers overgrew the simple literacy", - the newspaper "Russian idea" wrote in $190{ }^{5}$. Thus, the idea of a public university fell on a fertile soil. Beginning as popular lectures on general educational subjects (1897-1898 years) public universities extended and improved forms of their work. Organizers of courses tried to make lectures more accessible to students even with a low level of educational preparation. For this purpose brief prospectuses on each branch of knowledge leading students to questions offered for studying were issued. A commission on the project of courses development was created. Well known teachers took part in it. The program of courses was a new word in national didactics. It was notable for the depth of the contents and for careful reasonableness in selection of a teaching material, and it was precisely oriented to the audience. In 1903-04 years I.M.Sechenov delivered lectures on anatomy and physiology ${ }^{6}$. He spoke with delight about the pedagogical skill of teachers. Recollecting a teaching manner of the chemist M.I.Konovalov, Sechenov wrote: "In my life I have never heard such a skilful adaptation of serious reading to the intellectual level of the audience. Obviously, lectures were conceived and executed so that any step forward had the basis in previous lectures. Making such a step, the lecturer asked the audience what had formed the basis for this step, and each time the true answer was heard from the audience. But it is necessary to note that lectures did not differ at all in the contents from the lectures for university students."

In this connection we can mention the Public University of A.L.Shanjavsky. It was open in Moscow in autumn of 1908 on donations (300 thousand roubles) of the known public man and patron of art A.L.Shanjavsky. By scale of its educational and scientific activity this University had no analogues in the West. The training of students was conducted in two cycles: popular scientific and academic. The purpose of the popular scientific cycle was to prepare the students without high school knowledge for academic studies. The academic cycle aimed at giving students the regular higher scientific education. The curriculum of the academic branch included all basic subjects of the university course. Here delivered lectures N.E.Zhukovsky, A.E.Fersman, N.D.Zelinsky, P.P.Lazarev, G.V.Vul'f, K.A.Timirjazev and others. In laboratories equipped with a new-type machinery magnito-metric researches of rotating bodies were carried out, the researches becoming a basis of the domestic chrystallography. The University had no right to give its graduate diplomas about higher education and did not demand passing examinations from students. However, those who wished to pass exams and tests could do it and receive appropriate certificates. In 1912-13 at the Shanjavsky University permanent courses on cooperation, nonscholastic out-of-school education, library business, improvements of professional skill of doctors were open. These courses had a great popularity. So, the library course which began the library education in the country annually gathered up to 200 persons from all regions of Russia ${ }^{7}$. Thus, we see how needs in development not only improved old forms of national education, but also created new ones.

Further, the Soviet state while using the pre-revolutionary base created a system of general and vocational training, due to which (despite of the hardest social shocks - revolution and wars) the growth of the educational level of the population, high literacy, the development of science and engineering was provided. A considerable contribution to the solution of these problems was made by the education by correspondence. The data of the population census let us see literacy changes in the country ${ }^{8}$.

"Proceedings of the 2003 American Society for Engineering Education Annual Conference \& Exposition Copyright (C) 2003, American Society for Engineering Education" 
Table 1. The percentage of literate persons at the age of 9-49 years.

\begin{tabular}{|l|l|l|l|l|}
\hline Year & 1897 & 1926 & 1939 & 1959 \\
\hline$\%$ & 28.4 & 56.6 & 87.4 & 98.5 \\
\hline
\end{tabular}

The idea of organizing the education by correspondence arose simultaneously in Russia, Great Britain, Germany, the USA and some other countries. It was preceded by various kinds of self-education with the help of manuals and magazines. Along with the stationary form of a public university, on the boundary of the XIX - XX centuries in Russia there appeared also the education by correspondence. The initiative of creation of a national external higher school belonged to the Moscow Society of distribution of technical knowledge. (From here on the terms "external" and "by correspondence" are considered synonymous.) In 1895 at the educational department of the Society the commission on the organization of the domestic reading developed detailed regular plans and programs on various branches of knowledge, bibliographic indexes, lists of questions for control ${ }^{9}$. Training was conducted by correspondence. To the persons who have expressed a desire to be engaged in self-education under the direction of the commission, necessary books and brochures were sent, the subjects of abstracts were offered. About 150 professors and teachers of Moscow University and other educational institutions took part in the work of the commission. The professor of history from Moscow University P.G.Vinogradov headed the commission. In January 1897, the commission had 449 subscribers (73,5\% - men and 26,5\% - women). Basically, they were people's teachers and employees, mainly young people of $20-25$. More than half of trained men had the education below secondary, 33\% - completed secondary education. Among women, $25 \%$ were with unfinished secondary, $75 \%$ - with secondary and even higher education. Juridicial, philosophical, physical and chemical, literary and historical, and encyclopaedic departments were especially popular. At the beginning of the XX century the external public university of the Society for distributions of technical knowledge expands its activity. Alongside with written consultations, departures of lecturers to the province are organized for delivering lectures on various subjects for subscribers and all interested persons. The literary critics J.I.Ajhenval'd, P.S.Kogan, the teachers V.P.Vakhterov, N.V.Samsonov, the jurists M.N.Gernet, A.V.Gorbunov, L.A.Komarovsky, the musicologist D.S.Shor, the botanist A.F.Flerov, the mathematician I.I.Chistjakov, the historian J.V.Got'e, the archeologist N.G.Tarasov, the social scientists S.A.Jashchenko, P.N.Sakulin took an activ part in the work of the commission.

In 1908 in St. Petersburg the first All-Russia Congress of representatives of public universities and other educational institutions established on private initiative was held ${ }^{10}$. The Congress gathered 478 delegates representing 92 educational organizations from 36 cities of the country. Problems of self-education societies, the edition of the national encyclopaedic literature, deepening contents and perfecting a technique of nonscholastic adult education, cinema application in public universities, the importance of general educational excursions were included in the Congress agenda. In the resolution of the Congress it was recognized expedient to organize external educational courses. The care of the organization of these courses was undertaken by educational and pedagogical societies. By that time 135 such societies operated in Russia ${ }^{11} .8480$ members took part in their work. Societies contained 69 educational institutions, 36 libraries and reading rooms, 17 book shops and warehouses.

"Proceedings of the 2003 American Society for Engineering Education Annual Conference \& Exposition Copyright (C) 2003, American Society for Engineering Education" 
Thus, at the initial stage of development the education by correspondence depended on the individual initiative of separate scientists and organizations; it had no scientifically carried out system of functioning and was limited to studying separate subjects.

After the revolution sharply changed social conditions derivated a number of new requirements made by the society to education. Under the hardest conditions of economic dislocation and famine, when the personnel structure of the higher school sharply worsened (among 6 thousand professors and teachers only units had accepted ideas of the revolution), it was necessary not only to raise literacy of the population but also to change a class composition of students. New rules of the admittance established by a Decree of the Russiun Federation Councel of People's Comissars of August, 2, 1918, cancelled entrance examinations. Entrants from workers and peasants could enter any higher educational institution without presentation of a diploma, a certificate or a document about finishing any school. It should be taken into account that the educational level of the population layers among which students were collected was so low that it did not give them an opportunity of studying at higher schools. Therefore in the 20th years in the country a network of workers departments was created with the purpose of an accelerated preparation for higher school. The first workers department was opened February, 2, 1919 at Moscow Commercial Institute (nowadays - the Economic Academy named after G.V.Plekhanov) on the basis of preparatory courses ${ }^{12}$. In our opinion, the experience of workers departments should be analyzed in detail, as some its elements: forms of a dialogue between a teacher and students, group discussions, the organization of individual and independent work can be taken into consideration when organizing a modern educational process, in particular, for transitive courses, which allow to liquidate blanks in knowledge.

Simultaneously with it, various forms of education by correspondence became widely spread. The literature instalment for self-education was increased: "A school at home" under N.K.Krupskoj's edition, "A public university at home", "A workers' department at home", "Prepare to higher school", "Study yourself", "Pedagogical courses at home", "I am my own agriculturist ", "Academy of foreign languages" and others. In structure and contents these editions came nearer to modern methodical manuals on the external education. The material was arranged in a definite system; tasks for independent work and questions for self-checking were also given ${ }^{13}$.

We shall produce a brief chronology of basic stages of the external education in our country ${ }^{14,15}$.

\begin{tabular}{|l|l|}
\hline 1919 & $\begin{array}{l}\text { The 8-th Congress of the Bolsheviks' Party made a decision to render the all- } \\
\text { round state help to self-education and self-development of workers and peasants. }\end{array}$ \\
\hline 1924 & A Workers-and-peasants University by radio was established. \\
\hline $1923-$ & $\begin{array}{l}\text { Various courses with the external form of training were open, including external } \\
\text { courses of retraining teachers of the Moscow province, that carried out their work } \\
\text { in form of abstracts, written reviews and student conferences. Later, the system of } \\
\text { external courses of different purposes with various terms of training extended. At } \\
\text { first, they were courses on separate subjects or cycles of disciplines; gradually } \\
\text { they passed to the education with programs of average and higher educational } \\
\text { institutions. }\end{array}$ \\
\hline
\end{tabular}

"Proceedings of the 2003 American Society for Engineering Education Annual Conference \& Exposition Copyright (C) 2003, American Society for Engineering Education" 


\begin{tabular}{|c|c|}
\hline $\begin{array}{l}1925- \\
1929\end{array}$ & $\begin{array}{l}\text { here existed external courses of foreign languages, of the Soviet construction, } \\
\text { ade-union movement, communication, cooperatives and others, the External } \\
\text { ommunist University, the External Production Academy. }\end{array}$ \\
\hline $\begin{array}{l}\text { Augu } \\
1926\end{array}$ & $\begin{array}{l}\text { The Education Commissariat of the Russian Federation decided to open branches } \\
\text { by correspondence at technical higher institutions. Such branches were open at the } \\
\text { Second Moscow State University (nowadays Moscow State Pedagogical } \\
\text { University named after V.I.Lenin), at the Mechanical Institute named after } \\
\text { M.V.Lomonosov, the Agricultural Academy named after K.A.Timirjazev and } \\
\text { some others. For by-correspondence students some information collections with a } \\
\text { teaching material and articles of scientific character were issued. External } \\
\text { departments were limited, mainly, to improvement of professional skill of experts } \\
\text { and the help in preparation for examinations. }\end{array}$ \\
\hline 1927 & $\begin{array}{l}\text { e scientific and technical section of the State Academic Council began to work } \\
\text { t a system of external education in the country. A basis of the education } \\
\text { ganization was authorized, a technique of training was outlined, requirements to } \\
\text { inuals for external students were determined. }\end{array}$ \\
\hline 1928 & $\begin{array}{l}\text { The methodical guidance of external higher and average educational institutions } \\
\text { was entrusted on the Central Board of higher technical education, in the } \\
\text { framework of which the Main Institute of External Education was open in } \\
\text { Moscow. }\end{array}$ \\
\hline 1929 & $\begin{array}{l}\text { The Board of Education Commissariat ratified organization principles of } \\
\text { education by correspondence, planned a technique of training, requirements to } \\
\text { manuals for students, etc. }\end{array}$ \\
\hline $\begin{array}{l}\text { March, } \\
1931\end{array}$ & $\begin{array}{l}\text { The first legislative act about the education. } \\
\text { The decision of the Council of People's Commissars "About the system of } \\
\text { education by correspondence". } \\
\text { A special sector for such an education was organized. } \\
\text { In connection with a huge need in experts with higher education and qualified } \\
\text { workers the system experienced a rapid growth. At that period the largest external } \\
\text { institutes were organized. By the beginning of } 1931 \text { about } 350 \text { thousand students } \\
\text { had been trained under this system. }\end{array}$ \\
\hline $\begin{array}{l}1929- \\
1938\end{array}$ & ourse system of training. \\
\hline 1935 & $\begin{array}{l}\text { external educational institutions entrance examinations were introduced into } \\
\text { ractice. }\end{array}$ \\
\hline $\begin{array}{l}\text { August, } \\
1938\end{array}$ & $\begin{array}{l}\text { The decision of the Council of People's Commissars of the USSR "About the } \\
\text { higher education by correspondence" determined the nomenclature of specialities } \\
\text { and a network of independent external higher schools. } \\
\text { In all external higher schools and branches the course system of training and } \\
\text { obligatory internal exams were introduced. } \\
\text { Additional paid holidays were established for external students. }\end{array}$ \\
\hline
\end{tabular}

The further development of the education was suspended by the war. The number of students had reduced by three times by the beginning of 1943-44. However, in post-war years the system of the external education extended and improved.

"Proceedings of the 2003 American Society for Engineering Education Annual Conference \& Exposition Copyright (C) 2003, American Society for Engineering Education" 
The general state of the higher external education in the USSR by the beginning of 196364 could be characterized by the following data:

The number of external higher schools -21 .

The number of external branches and faculties -607 .

The number of students $-1438,6$ thousand people.

Admittance - 356,8 thousand people.

Graduation - 105,1 thousand people.

On the eve of Perestroika the higher school kept a tradition of the external-evening training. As a rule, half the students studied at evening and external departments.

Thus, we can ascertain that during thirty years the powerful system of the external education was generated and legislatively registered in our country. Created in due time, in addition to day-time, the external form of training quickly stored up fresh energy and turned to an important means of preparation of qualified experts ${ }^{16}$.

Table 2.

\begin{tabular}{|l|l|l|l|l|l|}
\hline Years & $1914-1915$ & $1940-1941$ & $1965-1966$ & $1970-1971$ & $1976-1977$ \\
\hline $\begin{array}{l}\text { The total number of } \\
\text { higher schools in the } \\
\text { country }\end{array}$ & 105 & 817 & 756 & 805 & 859 \\
\hline $\begin{array}{l}\text { The total number of } \\
\text { students (thous.) }\end{array}$ & 127 & 812 & 3861 & 4581 & 4950 \\
\hline including: & & & & & \\
\hline the day-time form & 127 & 558 & 1584 & 2241 & 2711 \\
\hline the evening form & & 27 & 569 & 658 & 650 \\
\hline the external form & & 227 & 1708 & 1682 & 1589 \\
\hline
\end{tabular}

The external higher education is carried out by special external institutes and external departments of stationary higher schools as well as by their branches in other cities. The preparation of experts is carried out on the majority of specialities of stationary higher schools, except for those that require the regular guidance and control on the part of teachers (for example, medicine, actor's skill, painting, etc.). The contents and the order of training are established by the curricula authorized for each speciality by the Ministry of Education. Programs and textbooks are common for day-time, external and evening higher schools. In addition to them, methodical instructions with recommendations for independent work, an additional material to textbooks, and also examples, tasks and questions for self-checking are compiled for external students on each subject. The subject-course system of training provides passing examinations within an academic year, without breaking a sequence and interrelation of disciplines within the limits of the given curriculum.

The preparation of external students consists of the following basic kinds of study:

- introductive lectures that acquaint students with the general character and methodical principles of the given discipline and set forth the most important and difficult scientific-theoretical questions;

- seminars, laboratory and other practical classes;

- course designing and course works;

"Proceedings of the 2003 American Society for Engineering Education Annual Conference \& Exposition Copyright (C) 2003, American Society for Engineering 
- internal and external consultations;

- course tests an examinations;

- state examinations, diploma works or diploma projects (depending on a higher school);

- now external students have the right to a paid educational holiday of 40 days ${ }^{17}$.

For years of its existence the external form of education enableded thousands of our fellow citizens to acquire a profession. Why is it so attractive? Comparing social motives of training students at day-time and external departments, it can be seen that a student of a daytime department quite often studies at the request of his or her parents. The student has no precise vocational orientation and chooses a speciality being guided, mainly, by its prestige, by the availability of military chairs or the system of deferment. For external students the predominant motives of study are: the prospect of promotion or the necessity of diploma confirmation of their positions. By combining work with study, the student has an opportunity not only to receive knowledge, but also to get some labour experience that opens to him a chance of fast career and excludes an adaptation period which is inevitably experienced by a young specialist. As a rule, external students have no problems of dwelling and life. Besides, the external form of education is practically indispensible for those who has to combine labour activity with study. That is why the number of external students is stably about $30 \%$ of the total number of students in Russian higher schools ${ }^{18}$. Under conditions of developing market relations, the advantages which are given to the student by the external system of training essentially raise its chances not only of a survival but also make it more competitive in relation to other forms of training.

However, it should be recognized that there are many researchers who do not share the existing point of view about the role of the external form of training. They emphasize that "cheap" education is not what can be thought if we count up total expenses of the society and pay attention to the quality of graduits. In some cases they are considered as students of "second sort". The level of requirements to them is lowered. This is done with "kind motives", but it results in washing away the concept of higher education.

Undoubtedly, the system of the external education which was very fruitful in 30-70 years becomes outdated and is insufficient for modern conditions. Moreover, in order to meet the requirements of tomorrow, it should be improved. And there are reserves for such a perfection.

First, it is possible to improve the quality of adjusting lectures. It is unreasonable to copy the methods accepted at the internal form of training. An attempt to deliver maximum lectures as fast as possible led to the situation when students have rather vague idea about the subject. They come to the conclusion about impossibility of mastering it. A result of it is cribbing and unfair attitude to study.

Second, an external student needs a qualitative didactic material (methodic instructions and manuals). During an inspection carried out by a laboratory of the Research Institute of Higher Education in 1998, deterioration of fund acquisition of higher school libraries was revealed: the volume of the educational literature reduced by $10 \%$ due to losses, obsolete and decayed books and also because the libraries purchased less new books on account of financial difficulties. In comparison with 1994, the receipt of a new educational literature to libraries was reduced almost by 5 times. If earlier there were 12-14 textbooks per student, now only

"Proceedings of the 2003 American Society for Engineering Education Annual Conference \& Exposition Copyright (C) 2003, American Society for Engineering Education" 
1,5 - 2 units. Circulations of the textbooks issued by central publishing houses were sharply reduced, their price has grown. New textbooks even having the signature stamp of the Ministery of Education of Russia, are bought by libraries in individual copies. Due to particularity of the education by correspondence, the volume of independent work of a student in the total amount of his preparation work is especially high, but frequently the student is not ready to its rational organization.

So, it is necessary to form skills of this work with the help of methodical instructions. Therefore, higher school professors themselves have to compile manuals for students of this form of education. The independent work of students must be used more effectively by introducing new information technologies in education.

Such a form of education by correspondence is practised by many countries and is called "distance learning".

The analysis of a world experience of university centres shows the popularity increase of this form of education. The editor of the magazine of UNESCO "Perspectives" Zaglula Morsi underlines ${ }^{19}$ that the development of the external education is considered as a peace revolution which is capable to change radically all the process of training and professional training, due to its availability to various layers of the population, to its economic advantages and the speed of knowledge dissemination.

\section{Bibliography}

1. The concept of modernization of the Russian education for the period till 2010. // Higher education today. 2002, № 2, p.2-14.

2. Korol'kov V., Vzjatyshev V., Romankova L. Personnel policy in the higher school: problems and tendencies. // Higher education in Russia. 1999, №2, p.7-17.

3. The Big Soviet Encyclopedia. M.: Pub. "The Soviet encyclopedia", 1971, p.554.

4. Rashin A.G. Formation of working class in Russia. M.: 1958, p.580.

5. Russian idea. 1900, № 1, p.173.

6. Workers' courses in Prechistenka. The first workers' university in Moscow. - The collection of articles and memoirs. M.: 1948, p.143.

7. Tebiev B.K. From the history of public universities in Russia. M.: 1987, p.41-46.

8. The pedagogical encyclopedia. V.1. M.: The Soviet encyclopedia. 1964, p. 612.

9. Arabazhin K.I. A public university in Saint-Petersburg. SPb.: 1898, p.12-13.

10. Works of the first All-Russia congress of figures of societies of public universities and other educational establishments of private initiative. St.-Petersburg, January, 3-7, 1908. SPb.: 1908, p.26-63.

11. Tebiev B.K. On the boundary of centuries. The government policy in the field of education and the publicpedagogical movement in Russia at the end of XIX century.

12. Pedagogics of the higher school: the manual. The Leningrad state pedagogical institute, 1974, $116 \mathrm{p}$.

"Proceedings of the 2003 American Society for Engineering Education Annual Conference \& Exposition Copyright (C) 2003, American Society for Engineering 
13. Djushen B.V., Zarovniadny N..A. Reference book on self-education and instruction by correspondence. M. - L., State Publishing House, 1929, 179 pages.

14. The higher school of the USSR for 50 years (1917-1967) / Under.red. of V.P.Eljutin. M.: The Higher School, 1967, 272 p.

15. The higher school. The basic decisions, orders, instructions. / Under. Red. of L.I.Karpov and V.A.Severtsev. M.: The Soviet science, 1957, 676 p.

16. Dobrynina V.I., Dobrynin V.V., Kuhtevich T.N., Tumanjan O.V. The society - the higher school - the youth. M.:NIIVO, 1995.

17. Zimakov I.E., Petrenko A. Education by correspondence and its specificity. // Higher education in Russia. 1995, № 4, p.40-45.

18. Zimakov I.E., Mel'nik B.E., Sjomina N.A. Education by correspondence in modern Russia. // Higher education in Russia. 1995, № 1, p.73 - 39.

19. Education by correspondence in foreign countries: concepts, practice, prospects. Scientific-analitical review / AS of the USSR, M.: INION, 1990, 99 pages.

\section{Biographical Information}

Tatiana BURUKHINA - Master of Mathematics, Lecturer of the Higher Mathematics Department, Moscow State Social University, Moscow, Russia. Scientific interests - Pedagogical innovations in mathematics.

Michael DMITRIEV - Doctor of Mathematics, Professor, Head of the Applied Department, Moscow State Social University, Moscow, Russia. Scientific interests - Singular perturbations in control systems, System analyses, Pedagogical informatics. E-mail: mdmitriev@mail.ru

Galina ZHUKOVA - Doctor of Mathematics, Professor Head of the Higher Mathematics Department, Moscow State Social University, Moscow, Russia. Scientific interests - Asymptotic metods, Differential equations, Pedagogics of higher education.

Valery SOKOLOV - Ph.D., Professor, Head of the Theoretical Informatics Department, Yaroslavl State University, Sovetskaja st. 14, Yaroslavl, 150000, Russia. Scientific interests - Theoretical and pedagogical informatics. E-mail: sokolov@uniyar.ac.ru

"Proceedings of the 2003 American Society for Engineering Education Annual Conference \& Exposition Copyright (C) 2003, American Society for Engineering Education" 